\title{
ECONOMIC-POLITICAL CAUSES OF TAX EVASION (THEORETICAL BACKGROUND) $^{1}$
}

\author{
KAROLÍNA ČERVENA2, ANNA ROMÁNOVÁ
}

\begin{abstract}
This paper is focused on tax issues, with an emphasis placed on the identification of primary causes of the economic-political nature of the emergence of tax evasion and non-compliance with tax obligations. The aim of the Authoresses is to provide in the context of this paper a brief overview of the economic-political background leading to detection of the real causes of the emergence and existence of tax evasion and non-compliance with tax obligations. In carrying out complex analysis of the causes leading to the emergence of tax evasion and non-compliance with tax obligations, it is necessary to also accept the nature of non-economic determinants. Instability or turbulence of the conditions in the context of the economic milieu (e.g., frequent changes in the tax code) significantly increase the complexity of the disclosure of the real underlying cause of tax evasion and non-compliance with tax obligations. The apparent underlying cause of the emergence and existence of tax evasion is inherently taxation, that is, the introduction of taxes as such and the obligation to pay them. The decisive factors leading to the creation of tax evasion and non-compliance with tax obligations include the factors of economic-political

1 This paper has been written as a partial output of the APVV-16-0160 research project, Tax evasions and tax avoidance (motivation factors, formation and elimination), as well as the output of the VEGA 1/0375/15 research project, Tax evasion and tax frauds and possibilities of their prevention (by means of tax law, commercial law and criminal law).

2 Doctor, Researcher at Pavol Jozef Šafárik University in Košice, Faculty of Law. Within her research and teaching activities, she pays special attention to assorted micro- and macroeconomic issues from the interdisciplinary perspective. She is the author of more than 80 reviewed scientific outputs in the form of articles in journals, chapters in monographs, conference papers. She is a member of the Information and Organization Centre for Research into Public Finances and Tax Law in the Countries of Central and Eastern Europe. Contact email: karolina.cervena@upjs.sk

3 Doctor, Rsearcher at Pavol Jozef Šafárik University in Košice, Faculty of Law. Her specializations are direct taxation, local taxes, and tax administration. She is the author of more than 35 reviewed scientific outputs in the form of articles in journals, chapters in monographs, conference papers. She is a member of International Property Tax Institute, Toronto and Information and Organization Centre for the Research on the Public Finances and Tax Law in the Countries of Central and Eastern Europe, too. Contact email: anna.romanova@ upjs.sk.
\end{abstract}


nature within the meaning of the concept and implementation of the taxation policy as part of the economic policy of the State.

\section{Keywords}

Tax evasion; tax policy; taxation

\section{JEL Classification: D63, H21, H26}

\section{Introduction}

In identifying the causes of the emergence and existence of tax evasion and noncompliance with tax obligations, it is necessary to apply the theoretical knowledge from multiple fields of science with the aim of providing a comprehensive look at this set of issues. The concepts of tax evasion and non-compliance with tax obligations should be understood for the purposes of this paper in the broad sense of the word - which includes both illegal ${ }^{4}$ and legitimate ${ }^{5}$ the action of entities (Stieranka, Sabayová, Simonová, 2016: 78-79). The Authoresses have focused in their paper on finding and describing fundamental and potential sources of the emergence of tax evasion by employing standard methods of scientific research. Within the framework of the examination of these issues, the Authoresses have given priority to applying theoretical (and practical) knowledge from the fields of economics and political economy, partly in interaction with some other pieces of knowledge derived from political science, law, psychology, and ethics. Identification of the causes that exert the real impact on the emergence and persistence of tax evasion and non-compliance with tax obligations is considered the starting point of the subsequent search for alternatives that provide instructions to deal with this phenomenon in the turbulent conditions and the globalizing economic milieu. Mises notes in his monograph that the flourishing of human society depends on two factors: 1. the intellectual abilities of extraordinary people to create sane social and economic theories, and 2. the ability of people to make these ideologies acceptable for the majority of people (Mises, 2006: 775).

\footnotetext{
4 In view of the awareness of one's own actions, intentional illegal tax evasion occurs in life as a result of an open or a hidden breach of applicable law, making use of error, bringing into error, nondisclosure of material facts on frequently shammed or belied actions having the nature of deception and leading ultimately to nonpayment of or reduction in the tax and the unintentional ones - these represent to tax-related actions by the taxable entity, who of carelessness or lack of knowledge of the tax regulations would reduce their own tax base or the tax itself (Stieranka, Sabayová, Šimonová, 2016: 78-79).

5 We do not consider legal tax "evasion" an illegal action, or rather, the result achieved is not related to a violation of law, but is a result of the use of options enabled by the current legal situation in the field of taxation (e.g. making use of alternatives within the framework of taxation legislation, taxation planning, tax liability swapping, etc.) - the macroeconomic effect would subsequently be reflected in the revenue section of the public budget.
} 


\section{Taxation - Selected Knowledge and Experience}

Application of theoretical knowledge and practical experience relating to taxation, originating in economics and political economy, is represented in economic practice by tax policy as part of the economic policy, and practical economic policy is a reflection of the political-economic arrangements of the economy of a particular country (even in the case of a grouping of sovereign states within an economic entity, provided these apply a common economic policy).

In the form of political-economic definition, from the primary historical perspective, there are only two types of organized economy, specifically a free market economy ${ }^{6}$, where isolated economic units come into contact with each other, cooperate through market and competition, and a centrally controlled economy, in which the economic actors are subject to a management center and perform their economic activity by the initiative of the instructions. Modification of the free market economy is represented by social market economy ${ }^{7}$, which is characterized by free pricing, protection of private property, stability of money circulation, competition, economic independence of entities, and the limited functions of the State - the essence of the functioning of the economy of this type is represented by a competitive environment, where the essential economic role of the State is contained in the creation and protection of a competitive environment without the existence of monopolies, as well as other structures controlling the market (e.g. monopson, oligopoly).

Today's reality is that modern types of the economy no longer exist in the form of an "ideal" economic arrangement; what exists are just their combinations or modifications. In the 1960s, a modified model of the social economy appeared in the form of a formed society, where politicians and civil servants were considered entities that pursued their own personal interests ${ }^{8}$ and objectives, and it is, therefore,

6 According to the neoliberals, the ideal free market economy will be realistically approached by those economies where the connection with the market is secured by public institutions. Note. Neoliberalism is a label for the new liberal theories, but also a label for a return to classical liberalism in the form of the teachings of the classical period of economics (A. Smith, D. Ricardo, J. B. Say, and others).

7 The social importance of market economy is linked to the idea that the economic benefit from the increase in the production of the work, rationalization, and innovation, should result in prosperity to all individuals in a society, and the State has to regulate the course of the reproductive process, in particular by the instruments of the monetary-credit nature. The model of the social market economy is based on the principle of subsidiarity, where efficiency and prosperity as a result of the operation of a market economy creates a resource for attaining social objectives, while social responsibility must be based on the individual, and State would only take over the responsibility in case of failure of the individual and the market structures, and also any action of the State in the social domain should be implemented in such a way that it does not compromise the functioning of the market mechanism, but also the social market economy should lead to efficiency and prosperity.

8 In mixed economies, there exist diverse (often differentiated) interests of individuals, private companies, public cooperative and solidary entities of the State. 
necessary to modify their behavior by law in such a way that they are forced to follow the interests of society as a whole (Červená, Čipkár, 2017: 38-50).

In the construction and in the implementation of economic measures, there emerges a conflict between the perception of economic issues in economic and political terms. In that context, it is necessary to contemplate about the question - what kind of impacts or effects of microeconomic and macroeconomic nature the given conflict causes. The optimal setting of the levels of taxation shall be based on and correspond to realistic objectives of economic policy in the long term with a view to the sustainable growth of the economy - the aim of the taxation policy, therefore, should not be maximizing revenues to the State budget, rather, maximizing the aggregate supply. For the economic development, expenses that correspond to the social awareness are definitely far more efficient than those that serve the interests of the planned system. The fiscal policy begins by determining the level of government spending, but there is no guarantee that a combination of expenditure policy and progressive taxation would create a reasonable level of demand (Galbraith, 1984: 423). Fiscal policy may be used to at least a partial correction of revenue inequality (the progressive rate of income tax has a social meaning in a market economy - it is a corrective to the distribution process), but the tax policy should not encourage a process of concentration (for example by turnover tax or special tax for corporations), thus making the business of monopolies more convenient (Eucken, 2004: 338-389).

The possibilities of the fiscal control of the economy by the action of discrete tax policy tools, which policy regulates the income of the population, whereby regulating the resources available for investment, have appeared inadequate or inefficient in recent years. Since the 1960s, the New Economics represents a modification of the Keynesian economic policy9. The possibilities of the fiscal control of the economy by the action of discrete tax policy tools, which policy regulates the income of the population, whereby regulating the resources available for investment, have appeared inadequate or inefficient in recent years. Since the 1960s, the New Economics has represented a modification of the Keynesian economic policy ${ }^{8}$, whose followers recommend to extract the fiscal policy from the principles of restriction, particularly from the principle of equilibrium of the budget, but they also attach great importance to the reduction of taxes for the purpose of stimulating economic growth $\left(\mathrm{Rahn}^{10}, 2007\right.$ : 228-230).

9 The concept of the New Economy is based on the assumption that a cyclic development is not regular, and the aim of the economic policy should be ensuring an equitable growth rate and full employment.

10 Richard W. Rahn served as the Director of the Centre for Global Economic Growth, he also collaborated with the Heritage Foundation, the Discovery Institute, and the Cato Institute, was a member of the Montpelier Society, and in the 1980s he also served as Vice President and Chief Economic Expert of the US Chamber of Commerce and the Chief Editor of the economic journal, Journal of Economic Growth. 
The idea of the representatives of the theory of rational expectations is directed to the recommendation that the national, but today also the transnational economy, be necessarily regulated by publicly known, obvious and understandable economic measures that are to monitor the strategic (long-term), not the ad hoc short-term goals. In this context, the neo-institutionalists ${ }^{11}$ who offer an interdisciplinary approach to examining economic problems in conjunction with other subsystems - political and sociocultural ones - point out that the long-term development of the society is completely different from the static market efficiency (they underline the volatile nature of economic reality). The institutionalists ${ }^{12}$ note that the social costs do not reflect the full extent of the market economy, which may have an impact on the results of the economic measures implemented. It is possible that new institutional theories (the Theory of Constitutional Economics, ${ }^{13}$ the Theory of Public Choice, ${ }^{14}$ the Theory of Property Right ${ }^{15}$ ) can provide guidance on the development and implementation of economic measures for the general beneficiary of economic results in the current globalizing marketing environment.

\section{Taxation in Mixed Economies Under the Influence of Integration and Globalization}

The issue of taxation was in the past and has been in the present dealt with by different groups of experts - economists, political scientists, lawyers, philosophers and others ${ }^{16}$ (Bujňáková et al.: 2015: 408). In addition to the positive views of

11 Neo-institutionalists emphasize the need for the creation of a new economic paradigm based on the synthesis of neoclassical and neo-institutional theories (e.g. publics microeconomics-a new microeconomic theory linked with the State sector and the principles of organization and economic conduct of business entities).

12 The economic direction in which its leaders have traditionally addressed position of power in the social system.

13 It explains the advantages and disadvantages of alternative legal-institutional-constitutional rules, which limit the choice and the activities of the economic and political entities when as a consequence of imperfect functioning of democracies, the executive power is withdrawing from the voters. The leaders of this theory sees the role of the legal rules in their ability to eliminate the abuse of power and competences of the executive branch, and, as their opinion has it, it is necessary to assess the existing alternatives in the construction of the constitutional framework of the society and sort them out according to their level of profitability, which would facilitate the choice of the best alternatives for those who are qualified to deal with legal changes.

14 This theory represents a radical approach to the State administration and the Government in the sense that most of the national activities could be left to the market, or their performance may be carried out by private companies.

15 It based on the idea that the economic system of any society is determined by its proprietary rights, and so if there occurs a change of ownership, it will cause a change in the behaviour of economic entities, which would result in a change in the distribution of income and the allocation of resources, and is also based on the assumption of the existence of economic agents (institutions), who restrict the level of independence of decision-making managers and on the existence of transaction costs, which crucially affect the behaviour of economic entities, while putting emphasis on the relationship between law and economics.

16 Taxation had been a topic for thinkers of the Antiquity (e.g. Aristotle), medieval thinkers (Thomas Aquinas), in the modern era there had existed different view groups (directions) of economists, such as the classical economists (for example, A. Smith, who had formulated four principles of taxation:1. people should contribute in proportion to their income; those who earn more should be paying more; 2 . taxes should be specific, not arbitrary, the maturity period and the method of payment should be clear to all; 3 . The tax maturity should be 
economists to taxation, such as those by the followers of post-Keynesian theories ${ }^{17}$ (Iša, 2006: 853-869), who are advocates of taxation of the affected pension policy (in the meaning that if the private economic entities place burden on the society by extreme costs, the government shall have the right to charge them taxes), we also meet with those in the negative (the leaders of classical economics, monetarists ${ }^{18}$, representatives of the Offer Party Economics ${ }^{19}$ ) notes that taxation constitutes a clear example of seizing private property with its effect on the status of private property and enforcing the right therewith associated.

In today's mixed economies, taxes are considered the most important source of revenue to the State, therefore they are considered important instruments for the implementation of economic policy. In addition to the tasks to be fulfilled directly by the State through the expenditure part of the budget, it is necessary to be taking notice of carrying out the performance of tasks by public territorial self-governments (Románová, 2010: 289-295), which is also funded by taxes (Románová, 2011: 6368 ) and fees, i.e. it uses the funding from the resources coming from individual economic entities on its functioning and the fulfilment of the tasks (which in practice we often perceive as public resources, whereas their economic origin is in fact of private nature). In this context, the setting of the optimal tax system, which would be targeted to and would support the long-term economic growth (whereby the society would be directed to the development of whole society) is essentially a permanent problem, since there exist conflicting opinions and views on the issue of taxation in the scientific and professional communities ${ }^{20}$.

According to Šafránek, taxes are a dynamic value, volatile in time ${ }^{21}$, politically greatly motivated, the issue of taxes ${ }^{22}$ is also one of the redistributive processes. In

benevolent to the payer to meet; 4. taxes should not be more costly than is necessary for the citizen and the State).

17 Post-Keynesianism is a heterogeneous direction of economic thinking, which creatively develops just Keynes' theory, but also builds on other scientific knowledge presented at the 1930 s, refusing any forms of economic liberalism and recommending to complement traditional forms of Keynesian economic policy.

18 They principally reject progressive taxation of revenues - M. Friedman (a significant representative of the Monetarism), rejects progressive taxation of revenues and suggests the introduction of the so-called negative income tax to replace the existing social programmes, while introducing the negative income tax would not require any additional costs, which would eliminate the costs associated with the functioning of the system of social-welfare programmes. An important part of the Monetarian economic and political reform is contained in the tax system and social policy reform.

19 According to the Economics of the Offer Party representatives, taxation policy inhibits the activity of individual economic to work, savings, and investment and, therefore, it is crucial to find such an optimal rate of taxation, which would correspond to the development of the economy as a whole.

20 For example, Prof. Brdlík, who served as the Minister of Agriculture of the Czech Republic in the years 19201921, and also as Minister for the Supply of People, stated that taxes and fees are transferred, either directly or indirectly (in the form of excise duties), in the production and burden, thus restrict competitiveness of the national economy with foreign countries (in Knespl, 1928: 6-7).

21 The long-term stability of the taxes is essential for long-term economic stability or strategic planning on both macroeconomic (national-economic) as well as micro-economic (entrepreneurial or individual) levels.

Departing from a well-known definition that the tax represents the legal, i.e. mandatory, non-refundable and non-specific payment to the public budget, so in this context, we may consider customs and duties, social insurance contributions, and local charges the "tax payment". 
addition to its other functions, the tax system ${ }^{23}$ performs two fundamental tasks: 1. funding the operation of the institutions that protect the citizens, but also the politicians (army, police, emergency services, courts); 2. redistributing the wealth from those who may spare it to those who lack it. With the growth of the wealth in the society, the volume of taxes that the State collects from citizens is growing. But we may assume that alongside with the increasing amount of taxes, the effort of the parties concerned to avoid the payment of taxes is also growing (Šafránek, 2016: 6-7).

Modern tax theory emphasizes two principles, specifically justice ${ }^{24}$ and efficiency ${ }^{25}$ (in addition to equitability and efficiency, the tax should be legally clear and transparent). Technically, the taxes constitute a transfer of funds from natural and legal entities in the public budget. This transfer, however, cannot function without additional costs, which reduce the overall efficiency of the economy. The aim of the tax systems should, therefore, by way of priority, be reducing the inefficiencies to the lowest possible level - in an effort to reduce administrative costs, it is necessary to take into account the interests of both of the parties involved in the tax negotiations; frequent efforts to facilitate work on the part of the public sector at the expense of private taxpayers are unacceptable, just as well as similarly-acting regular changes not reasoned by anybody (e.g. forms and content of the pre-print tax return forms). In relation to the taxpayer, any tax exerts two impacts, specifically: the impact of tax on retirement - it expresses the impact of tax on the taxpayer's net income (according to the amount of the tax, tax reliefs, deductible items, etc.) and the substitution impact - this has an impact on the choice of a taxpayer who has an opportunity to decide between multiple choices, such as goods and services, the factors of production, savings, leisure time (Šafránek, 2016: 9-14).

The current tax policies of most of the democratically developed countries are governed by the proposition that taxes should be levied on every citizen according to their "ability to pay" - the above principle refers to one of the postulates of social

23 In light of the current economic theory, we distinguish three primary functions of taxation: a) the allocation function (active operation with the result of re-allocation of resources); b) redistribution function (redistribution of the wealth of society); c) stabilization function (mitigating cyclical fluctuations).

24 Equitability is associated with the redistribution function of the taxes, and may be based either on the principle of the benefit (the taxpayer pays the tax in an amount that corresponds to their benefit from public services), or to principle of their ability to pay (the taxpayer is to pay as much tax as is their ability to pay). There exist two approaches: 1 . within the meaning of the horizontal equitability, taxpayers with equal equitability are to pay equitable tax; 2 . within the meaning of the vertical equitability, taxpayers with higher ability to pay are to pay higher taxes. According to Ricardo's equivalence, governments are not to finance tax reduction by loans; tax reduction is often considered to be a way of set the economy in motion - if people have more money, they should be spending more; as far as tax reduction is financed by loans, the effect of tax reduction will only be temporary - they will have to be repaid in the future, either by raising taxes or reducing other government expenditure.

25 The principle of effectiveness: its essence is contained in the requirement that taxes be as cheap as possible in terms of costs associated with taxes (administrative costs, costs for the collection of taxes, excessive load - due to high taxes, people cease to work or do business). 
justice. Both fiscal and non-fiscal objectives of taxation are mutually conflicting it is not possible to eliminate this discrepancy. The real nature of the problem of taxation should be recognized in a paradox - the higher taxes we have to be paying, the more they "undermine" the market economy (they are incompatible with the market economy), and thus the system of taxation itself. Taxes as instruments of the interventionist policy may be sorted into three groups: 1 . taxes leading towards a partial or total restriction of the production of certain commodities, which of course leads to intervention in consumption; 2. the tax misappropriating part of the income or wealth; 3 . the tax fully misappropriating the income and wealth. Tax laws often lead to a computational method, by which it seems that the generated profits are higher, in comparison with other methods of quantification of profit (e.g. the accounting method), which essentially leads to "hidden" raising the tax rates. Collection of taxes in order to finance the efficient provision of public services (protection of public order, defense of the country, protecting and securing the rights, etc.) may be considered generally beneficial and not restricting the freedom of individual until such time when taxation begins to cause the destruction of the market economy (e.g. high tax rates). Interventionism as an approach to economic policy is based on the consideration that interference with the property rights does not affect the amount of production; the confiscation interventionism is a negative manifestation - the range of production activities is regarded as given, as something that in no way depends on the form of a social order, that is merely considered random, the role of the Government is to ensure the "equitable" distribution of national income among the citizens; however, in a market economy such as dualism of two separate processes (production and distribution) in fact does not exist. Confiscation taxation leads to a slowing down of economic and technological development not only through its impacts on capital accumulation, it also arises the general trend towards stagnation and preservation of the way of doing business, which in a competitive market of the unrestricted market economy could not sustain. Today, the taxes (and contributions) often drain off a significant portion of the financial resources ${ }^{26}$ of entrepreneurial entities - which restricts their development or the expansion of their business, which exerts an impact on the economy as a whole (Mises, 2006: 194-725).

Taxation policy has always been a symbol of national sovereignty of the State, however, the development of European integration with the aim of forming a single European market requires from the Member Countries cooperation in tax matters (in the form of an exchange of information, harmonization or coordination of their tax systems). According to the claims of some experts on taxation policy 
and tax reform, tax harmonization (in the form of an explicit ${ }^{27}$ or even implied ${ }^{28}$ tax harmonization), in its final effect means higher rates of taxation and also discriminatory and double taxation of income that are saved and invested (Mitchell, 2007: 127-141; Bujňáková, 2013: 27-47). Wallerstein in his publication expressed a view that taxation is constantly growing by the impact of the fact that the world is becoming ever more democratized (Wallerstein, 2006: 58).

More significant changes to the tax systems of a number of the Member States of the European Union have been implemented in the second half of the 1980s in the light of the reform of taxes of the revenue type. A representative of the current French economics, Piketty, states that one of the most important innovations of the $20^{\text {th }}$ century in the field of taxation was the creation and introduction of a progressive income $\operatorname{tax}^{29}$, noting that this institution played a key role in reducing inequality in the previous century, but today it is threatened by tax competition between countries and he also notes that in the $21^{\text {st }}$ century, the role of taxation is shifting toward the idea of taxing financial capital, which should be implemented in the form of a global tax on capital (although the Author himself admits that it is a utopic idea as yet), he considers a global tax on capital an ideal form of regulation, which would preserve economic openness and benefits would be equitably distributed among individual States (Piketty, 2015: 540-567). In the context of ongoing processes, Siroký notes that all the States that are actively involved in international economic activities must respond today to the existence of the tax systems of other countries despite the fact that they have their own tax systems established as derived from their own traditions, their specific terms, policy consensus (Široký, 2010: 350). Schultzová expressed the view that failure to address many tax problems with their direct and indirect impacts on the economy of the State, as well as on the enforced common tax policy in the European Union, create substantial obstacles for the common European market, and according to her opinion, the situation is more complicated in this area in the direction that the fiscal policy of the Member States of the European Union is in fact governed by common principles, but the tax systems of its Member States are also characterized by their own differences mainly in the amount of the tax rates, in recognizing or not recognizing various expenses for tax

27 Explicit tax harmonisation arises, if the representatives of the countries agree to define the minimum or the same tax rates - it is obvious that in this form of tax harmonisation the taxpayers cannot benefit from a better fiscal policy in other countries and governments are not under any pressure from the competitive discipline in the market. 28 Implied harmonization occurs, if governments tax the income earned by citizens in other tax territories - for
example, in the form of the implementation of the "directive on the taxation of savings" basically requiring from the governments the collection of financial information on the investors based outside the country and the delivery thereof to the tax authorities of foreign States - this system of the exchange of information does not ultimately allow the taxpayers to benefit from better fiscal policies in other countries.

29 Progressive income tax and progressive inheritance tax were originally introduced into economic systems as a solution to the crisis in emergencies (e.g. war, conflicts, or natural disasters). 
purposes, in the adjustment of the tax base by attributable tax-deductible items, in depreciation, but even in the redistributive process itself (Schultzová, 2010: 224).

In terms of stabilization, the taxes are the most efficient that are aimed at greater equality (with corporate and personal tax contributing most to the equality of income). The more compact the tax system is, the fewer escape routes it has, the better it serves the principle of equality and stabilization. Stimulation of certain areas of economic activity is a widely recognized aim of special tax bonuses and escape routes. In practice, however, companies or individuals are much more likely to benefit in the planned system than the firms or individuals operating in a market system. In the current economy, it is considered proper to equally treat every form of enrichment, which means to use the standard tax rate, regardless of what follows from it ${ }^{30}$ (Galbraith, 1984: 423-425).

\section{Conclusions}

In carrying out complex analysis of the causes leading to the emergence of tax evasion and non-compliance with tax obligations, it is necessary to also accept the nature of non-economic determinants. Instability or turbulence of the conditions in the context of the economic milieu (e.g. frequent changes in the tax code) significantly increase the complexity of the disclosure of the real underlying cause of tax evasion and non-compliance with tax obligations. The apparent underlying cause of the emergence and existence of tax evasion is inherently taxation, that is, the introduction of taxes as such and the obligation to pay them. The decisive factors leading to the creation of tax evasion and non-compliance with tax obligations include the factors of economic-political nature within the meaning of the concept and implementation of the taxation policy as part of the economic policy of the State.

For a responsible and successful economy, an argument holds true that not just motives matter, what also matters are the outcomes. Taxation subjected entities would, therefore, not be interested in just what taxes and what amounts they are paying, but at the same time for what purposes the tax revenues are used, that is, whether the tasks (including the performance of the tasks of the social, educational, cultural nature) of the State ${ }^{31}$ and whether their performance is productive, whether it is directed to the development, expansion, and promotion of production, thus to

30 Or in the form of income from capital, income, inheritance, gift, etc.

31 State (its political, government representatives) would often try to increase or maintain their popularity in gaining as much as possible of the funds to the State budget, and their use is often uncontrollable effectively (e.g. a quasi "deferred tax", the repayment of the national debt is also necessary to consider - the taxation of future generations due to social and consumer waste - it is essentially a "hidden tax", indirect and progressive in time). 
the development of the national economy - good motives do not guarantee good economy). Successful economic management (both on the micro- and the macro levels) also includes an assessment of not just the intended consequences (e.g. the growth of aggregate supply), but also unintended but often serious side effects (e.g. response of the trade unions in redundancies of employees, environmental pollution, and some more).

Economic motives (sources) of non-performance of tax obligations and tax evasion are, inter alia, represented by high rates of taxation, insolvency, but also the efforts of economic entities (entrepreneurs) to maximize their profits ${ }^{32}$. Actions taken by entities and leading to the implementation of tax evasion contains an entire complex of factors and, therefore, to identify the root causes of tax evasion, taking an interdisciplinary approach is required - in this context, for example, German theorists in business ethics (e.g. K. Homann, H. Steinmann, A. Lohr) agree that they do not absolutely give the profit available to ethics - thus, under certain conditions, they allow priority to be given to profit (even at the expense of the reduction of taxes, non-compliance with tax obligations) - but this is a question for each individual or entity, their morality, and conscience - in that their freedom of expression and business is contained, but for what they carry their personal responsibility (Červená, Čipkár, 2017: 38-50).

An optimal taxation policy is a predominant prerequisite for the elimination of the reasons for the occurrence of tax evasion and non-compliance with tax obligations (at both national and supranational levels), which should be based on the classic principles of taxation and should also work in coordination with the measures to ensuring the elimination of undesirable economic activities of individual entities, including the politicians - the effect of optimization of taxation in practice is also influenced by several factors of a non-economic nature: political will, interest groups, morality of economic entities, the legal status (legal certainty ${ }^{33}$ or

32 In the national economies of the type of market-oriented and mixed economies, the achievement of maximum profit is considered the main motivator of the business and it is more than obvious that any kind of "restriction" (in the form of taxation, levies, etc.) in earning the maximum profit is, from a purely economic point of view, regarded a "brake" for the economic development.

In fact, we are very far from achieving legal certainty today, which stems from the inflation of legislation, as well as from the vast increase in the quasi legislative activities of the Government and the growing powers of the State officials - the paradox of our time is that we are governed by the people not because we are not being governed by law, but precisely because we are being governed by it. Today it seems to be the fate of the freedom of individual that it is protected by economists rather than by lawyers and politicians. The attention of the advocates of the legislation should be turned to the processes leading to final products (law standards) - legislation in democratic societies reflects merely the will of the majority within the group of the representatives of the citizens in the Parliament (legislators), who are often not better educated or "more enlightened" than those who had been outvoted. Another characteristic feature of the legislation in the current democratic societies is the belief that lawmakers in the legislative process represent the "thinking" of citizens. May their own justification be as it is, the fact is that representation, and in fact the legislation, is subject to completely different processes, compared to the ones that result in scientific and technological progress - despite all this, in legislation they constantly adopt decisions in a way different from the scientific realm (Leoni, 1991: 1-6). 
uncertainty, enforcement of law), but also individual and social expectations for the future.

\section{References}

Bujňáková, M. et al.: Dane a ich právna úprava v Slovenskej republike v kontexte daňovej politiky EÚ (Taxes and Their Regulation in the Slovak Republic in Context of Tax Policy of EU), Košice: Univerzita Pavla Jozefa Šafárika v Košiciach, 2015.

Bujňáková, M.: Je v Európe potrebná harmonizácia daní? (Is There A Need For Tax Harmonisation In Europe?) in: Vybrané otázky daňovej politiky Európskej únie a jej členských štátov (Selected Issues of Tax Policy of the EU and Its Member States), Košice: Univerzita Pavla Jozefa Šafárika v Košiciach, 2013.

Cakoci, K., Vojníková, I.: Východiská a prognózy miestnych daní (Bases and Prognoses of Local Taxes), in: Financie, účtovníctvo, dane 2014 so zameraním na súčasné problémy II. (Finance, Accounting, Taxes 2014, Focusing on Current Issues II.), Košice: Ekonomická univerzita v Bratislave, Podnikovohospodárska fakulta so sídlom v Košiciach, 2014.

Červená, K., Čipkár, J.: Etické a ekonomické aspekty hospodárskej politiky s akcentom na zdaňovanie v modernej dobe (The Ethical and Economic Aspects of Taxation in the Present Age), in: Dny práva 2016 - část III Karel Engliš - zdroj inspirace pro rozvoj práva i národního hospodářství (Days of Law 2016 - part III Karel Engliš - Source of Inspiration for Law Development and of the National Economy), Brno: Masarykova Univerzita, 2017.

Čipkár, J.: Daňová harmonizácia a daňová konkurencia (mýty a realita) (Tax Harmonisation and Tax Competition (Myth and Reality)), in: Vybrané otázky daňovej politiky EÚ a jej členských štátov (Issues of Tax Policy of the EU and its Memeber States), Košice: Univerzita Pavla Jozefa Šafárika v Košiciach, 2013.

Epstein, R.: A. Právo, ekonomie a politika (Law, Economics and Politics), Praha: Wolters Kluwer ČR, Cevro institut a liberální institut, 2010.

Eucken, W.: Grundsätze der Wirtschaftspolitik, sechste ausgabe (Principles of Economic Policy, Tübingen: J.C.B. Mohr, 1990), Praha: Liberální institut, 2004.

Galbraith, J.K.: Ekonómia a spoločenské ciele (Economics and the Public Purpose), Boston: Houghton Mifflin Company, 1973; Bratislava: Pravda, 1984.

Iša, J.: Nicholas Kaldor a postkeynesovstvo: teoretická a hospodárskopolitická alternatíva neoklasickej ekonómie (Nicholas Kaldor and Postkeynes: A Theoretical and EconomicPolitical Alternative to Neoclassical Economics), Ekonomický časopis (Journal of Economics) no. 9 (2006). www.ekonom.sav.sk.

Knespl, J.: Reforma daní př́ímých v zemědelství (Reform of Direct Taxes in Agriculture), Praha: Zemědělský ústav účetnicko-spravovědný Č.S.R., 1928.

Leoni, B.: Freedom and the Law, Indianapolis: Liberty Fund, 1991. 
Mitchell, J.D.: Daňová harmonizácia verzus konkurencia v Európskej únii (Tax Harmonization versus Competition in the European Union), in: Na obranu slobodného trhu (In Defense of the Free Market), Bratislava: Konzervatívny inštitút M.R. Štefánika, 2007.

Mises, L.: Lidské jednání: Pojednání o ekonomii (Human Action: A Treatise on Economics), translation Š́ma, J. et al.: Praha: Liberální Institut, 2006.

Piketty, T.: Le capital au xxi siécle (Capital in the 21st Century), Bratislava: Ikar, 2015.

Rahn, W. R.: Kl'úče na ceste k ekonomickému rastu a slobode a úloha vlády (Keys on the Road to Economic Growth and Liberty and the Role of the Government), in: Na obranu slobodného trhu (In Defense of the Free Market), Bratislava: Konzervatívny Inštitút M.R. Štefánika, 2007.

Románová, A.: Význam miestnych daní pre rozpočty územnej samosprávy (Importance of Local Taxes for Municipal Budgets), Miedzynarodowe Studia Spoleczno-Humanistyczne (International Social and Human Studies) no. 1 (2010).

Románová, A.: Miestne dane ako zdroj príjmov rozpočtov územnej samosprávy (Local Taxes as a Source of Local Budget Revenues), in: Verejné financie Slovenskej republiky - vybrané aspekty a tendencie vývoja (Public Finance of Slovak Republic - Selected Aspects and Development Trends), Košice: Univerzita Pavla Jozefa Šafárika v Košiciach, 2011.

Schultzová, A.: Daňové sústavy štátov európskej únie (Tax Systems of the States of the European Union), Bratislava: Ekonóm, 2010.

Stieranka, J., Sabayová, M., Šimonová, J.: Daňové úniky a daňová kriminalita v Slovenskej republike (Tax Evasion and Tax Crime in the Slovak Republic), Bratislava: Epos, 2016.

Šafránek, L.: Daně aneb cesta do otroctví? (Taxes or the Way to Slavery?) Praha: Orego productions, 2016.

Široký, J.: Daně v evropské unii (Taxes in the European Union), Praha: Linde, 2010.

Wallerstein, I.: European Universalism. The Rhetoric of Power, New York, London: The New Press, Praha: Slon, 2008. 